The Singapore Economic Review, Vol. 64, No. 5 (2019) 1057-1080

(C) The Author(s)

DOI: $10.1142 / \mathrm{S} 021759081950022 \mathrm{X}$

\title{
INDUSTRIAL POLICY: CHINESE DEBATE TO TAIWANESE FOUNDRIES
}

\author{
AN-CHI TUNG \\ Institute of Economics, Academia Sinica, Taipei, Taiwan \\ actung@econ.sinica.edu.tw \\ HENRY WAN* \\ Department of Economics \\ Cornell University, New York, USA \\ hyw1@cornell.edu
}

Published Online 10 June 2019

\begin{abstract}
This study explores Chinese realities of industrial policy. These facts attract global interest. They also caused China's Debate of the Century between prominent Chinese economists, Justin Lin and Weiying Zhang. After commenting on this exchange with evidential assessments, three questions are explored for technology-followers: (A) Can industrial policy against market failure also minimize government failure? (B) Can catching-up create win-win outcome by complementarity, rather than substitution? (C) Can leapfrogging trigger global innovation by co-evolution? TSMC from Taiwan suggests affirmative answers for all these three. Although its game-theory basis appears challenging for replication, exceptions may prove rules for further studies.
\end{abstract}

Keywords: Industrial policy; China; India; special economic zones; semiconductor foundries; TSMC.

JEL Classification: L63, O24, O25, O53.

\section{Motivation}

Emulating Adam Smith, Myrdal (1968) entitled his decade-long magnum opus as Asian Drama: An Inquiry into the Poverty of Nations, documenting the ravage of market and government failures in Asia, which is a mainstay for his 1974 Nobel Award.

By 2018, the total nominal GDP of the top three Asian states, China, India and Japan, shall exceed that of the United States and twice as much in PPP. Clearly, events have overtaken prediction. Most economists would follow the East Asian Miracles (World Bank, 1993) and ask whether and how government policies can be finessed against market failures.

An important factor here would be the advantage of backwardness. Mainly from studying Russia, Gerschenkron (1962) found that a latecomer enjoys advantages in industrialization, in certain circumstances. However, histories show that such advantage

\footnotetext{
* Corresponding author.

This is an Open Access article published by World Scientific Publishing Company. It is distributed under the terms of the Creative Commons Attribution 4.0 (CC-BY) License. Further distribution of this work is permitted, provided the original work is properly cited.
} 
belongs to Asia much more than to Russia. Also, this advantage remains limited for three reasons: (i) the inefficiency of state-owned enterprises (SOEs) pampered by the soft budget as found by Kornai (1979), (ii) the successful preventive measures by the more advanced countries against future competition that was observed by Friedrich List as kicking away the ladder and elaborated in Chang (2002) and (iii) the constraints on improvement engineering (also imperfectly perceived as the Middle-Income Trap) affected even Japan, the most advanced East Asian economy (Hamada, 2003). ${ }^{1}$

Issues of whether and how one can deploy industrial policy to balance government failure against market failure has been passionately discussed between Justin Lin and Weiying Zhang (the two most influential economists of China today), in what is known as the Debate of the Century in China (China Economic Net, 2016). The global relevance of their issues on industrial policy and sector targeting is of keen interest to Basu (2017), former Chief Economist of the World Bank and Chief Economic Advisor to the Government of India, for Indian reform.

This study proposes that, against the afore-mentioned trilemma of industrial policy, technology followers can pursue the following strategy, successfully deployed in Taiwanese foundries, in the case of TSMC and UMC:

(i) against the soft-budget trap of Kornai: spinning-off by industrial policy to maximize market functions;

(ii) against antipathy from advanced economies: focussing on win-win specialization;

(iii) against the limit of emulation: innovating in business method to spur coevolution.

Such a strategy is based upon information, motivation and credible commitment for confidence-building. A game-theoretic analysis is presented in Appendix A. Although the TSMC example is challenging to replicate, the exception proves the rule, hence our analysis can reach issues involving motivation and behavior, which are aspects special for social sciences.

In the rest of this paper, Section 2 presents the Lin-Zhang exchange, first with Zhang's synoptic thesis against industrial policy and then Lin's closely reasoned rejoinder. This is followed by a brief summary of both their differences and many agreements between these two. To comment on their exchange, Section 3 examines three empirical cases each about a different type of industrial policy. This discussion brings up three intriguing questions, at the core of industrial policy that are keys to all catching-up growth. Section 4 returns to an India-China comparison for further insights. Finally, additional remarks are included in Section 5 as conclusion.

\section{A Synopsis of the Lin-Zhang Exchange}

\subsection{The case against industrial policy by Zhang}

We start with the integrated thesis against industrial policy by Zhang. This comprises a historic perspective on growth and development and ranges over a broad sweep of topics

\footnotetext{
${ }^{1}$ The last point vouchsafes the logic of Gerschenkron, in that the advantage fades out with the reduction of relative backwardness. For example, in 2011-2016, Japan's GDP grew at 1\% per year when compared with 9\% in the 1960s by World Development Indicators.
} 
discussed in modern economic theory: economic planning, uncertainty, creative destruction, entrepreneurship, rent-seeking, loss from distortion and the perversion of market signal and incentive, stimulants in recession and debt burden.

To Zhang, economic history testifies for the serendipitous nature of innovation, and the process of creative destruction makes the modern times increasingly unpredictable. It follows that the planned economy does not work and that entrepreneurship and market mechanism must be left alone from government interventions. Yet, for the sake of rentseeking, economic planning is often brought back, in the guise as industrial policy for picking winners. Such actions distort market incentives and cause repeated failures. Even during recession, stimulation efforts create fake jobs at the price of real debts.

After citing Chinese efforts in a sequence of sectors, from electric fans in earlier days to new energies in recent time, Zhang came down to the conclusion that with very few exceptions, all efforts in adopting industrial policy end up in failure and disappointment.

\subsection{The case for industrial policy by Lin}

To Lin, industrial policy is by nature a trial-and-error process. In economic development, most attempts at industry policy may have failed. But history also shows that industrial policy is necessary for every success, and success does not come by sheer chance. There are principles by which trials are to be made, also errors to be avoided when possible and managed if necessary.

It is important to identify one's own potential comparative advantage for exploitation. This may be done with a compass economy as template, selected by certain criteria: similarity to oneself, proven record of success and a modest difference in per capita income to be relevant. Government failure is more likely due to over-reaching. When in error, waste must be avoided in futile doubling-downs, like with a soft budget.

Successful examples abound in history: Britain emulated successfully the Low Countries, the US and Germany emulated Britain, Japan emulated the developed countries in the West, the Asian NIEs emulated Japan and China emulated all its Asian neighbors (Chang, 2002).

However, one should be aware that against potential competition, advanced economies often do not welcome to be targeted as templates, which may then lead to the Thucydides Trap (e.g., Allison, 2017). ${ }^{2}$

\subsection{General comments}

What one might easily miss is the broad agreement between Lin and Zhang. They are both against economic planning and for an outward-looking policy stance. And they share the preference for China to continue reform for development.

\footnotetext{
2 As an example, in the 19th century, in the face of followers, such as Germany and the US, Friedrich List claimed that Britain "kicked away the ladder" (Chang, 2002). Then, in the late 1980s, the US launched a trade war against Japan, at the appearance of The Japan that Can Say No (Ishihara, 1991). These are relevant to how the US reacts to Made in China, 2025 today.
} 
A main difference between the two is that Lin believes that government can make positive contributions, better than laissez faire advocated by Zhang, who worries about government failure.

\section{Evidential Assessments}

To comment on the Lin-Zhang exchange, we present three examples, each a selected specimen of industrial policy. The first two examples are from Chinese records and the last one, across the Taiwan Strait. The juxtaposition of the experiences from both Taiwan and China serves two purposes. First, recently available sources from Chinese archives show how Taiwan's development served as a template, as considered essential by Lin, for the Chinese reform under Zhou Enlai and Deng Xiaoping. See elaboration in Section 3.2. Secondly, the above experience helps to identify the core notions for industrial policy which are replicable across the Taiwan Strait, under globalization, in spite of the differences in institution and economic size. This is interesting to economists like Basu in India and elsewhere for catching-up growth.

\subsection{Market for technology: The HSR in China}

At the center of Zhang's thesis, the market force is decided by world demand and supply and should not be influenced by government policy. Solar panel, for example, is the most recent case cited by Zhang as a failed policy leading to over-capacity. ${ }^{3}$

Yet for large countries such as China and India, if the government looks on with folded arms, the economy may fare worse than with government intervention and may even suffer from immiserizing growth in some cases (Bhagwati, 1958).

What confirms Lin's discourse about whether and how industrial policy works is the case of HSR for China. Here China took Meiji Japan ${ }^{4}$ as its compass economy in offering market access for technology to four multinational firms, Alston, Bombardier, Kawasaki and Siemens, requesting technology transfers to develop its own national standard in HSR (Chen and Wang, 2010).

About whether industrial policy works, one takes note that in one decade, the total length of Chinese HSR has reached almost $70 \%$ of the world total mileage by 2017 . The success in technology transfer is testified by the subsequent export of 18 HSR projects: either completed, under construction or planned by 2017 (Kynge et al., 2017).

About how industrial policy works by using a compass economy, China did not just use tariffs in the first mover's game. Instead, it took advantage of the mutual rivalry among the four multinationals in the game of prisoners' dilemma (McKinsey, 2011). Siemens initially

\footnotetext{
${ }^{3}$ However, with a broader perspective and in hindsight, one may argue that the policy is not a total failure in three ways. Chinese output expansion has ameliorated local environmental hazard, created domestic capability to build giant solar farms abroad and reduced cost of solar power worldwide against global warming (Baraniuk, 2018).

${ }^{4}$ After its victory in 1895, Meiji Japan regained the power to impose tariffs, used it to induce tariff jumping by General Electric and Western Electric from the US and Siemens from Germany to transfer technology of electric machines that Japan could not develop alone at that time (Uchida, 1991). As in a Stackelberg duopoly, the first mover in the model earns more profit than a conventional Cournot firm.
} 
demanded better terms, but had to compromise, after being left out in the first round and suffered plunges in stock price (Chen and Wang, 2010).

\subsection{Learning by exporting: Shenzhen special economic zone}

A second example of the application of industrial policy in China is the establishment of Shenzhen Special Economic Zone (SEZ) almost four decades ago. For China, the launching of Shenzhen SEZ is a major policy initiative, deploying varieties of instruments. This is close to Lin's pro-growth stance, at variance with the laissez faire preference of Zhang.

In 1972, premiere Zhou Enlai of China had informed both Whitlam, the Australian prime minister, and Rockefeller, the American banker, that remarkably Taiwan exported many products with foreign support just like Hong Kong did, from its Kaohsiung Export Processing Zone (KEPZ), and China ought to try the same. Deng Xiaoping explored the project after Zhou passed away. Although interrupted by his own temporary purge, on returning to power, Deng delegated Xi Zhongxun (father of President Xi) to develop the SEZ at Shenzhen with full discretion, when the foreign exchange was in severe short supply for the government (Chen, 2008).

In 1980, Shenzhen became China's first SEZ and grew remarkably until today. By 2017, its GDP overtook Guangzhou and is neck-and-neck with Hong Kong. Moreover, Shenzhen is just part of the Chinese network of Special Export Zones. After fiscal reform and administrative devolution, different zonal administrations compete against each other, turning their bureaucrats into helping hands rather than just grabbing hands (Yao, 2011). This development can be seen as an innovative adaptation relative to Hong Kong and KEPZ, its templates.

KEPZ, the template for Shenzhen, was the brain-child of K. T. Li for Taiwan to emulate Hong Kong in the early 1960s. ${ }^{5}$ It combines the features of Shannon of Ireland as an industrial park, ${ }^{6}$ and Trieste of Italy as a free port, ${ }^{7}$ serves to share win-win gains with all trading partners. Its success received worldwide attention, also foreshadowed the economic aspects of today's charter city model, favored by Paul Romer (2015), the immediate successor of Basu as the World Bank's chief economist.

Yet such a policy has not yet been systematically studied in either theory or history. In theory, the SEZ is based on the principles that eventually appeared in the literature, by analyses of Arrow (1962), ${ }^{8}$ Bhagwati (1999) ${ }^{9}$ and Stiglitz and Greenwald (2014) ${ }^{10}$ on

\footnotetext{
5 It is based on Hong Kong's positive non-interventionism, which won the praise of Milton Friedman (1998, 2006).

${ }^{6}$ This enables learning-by-doing, including assembly operations (by the Watanabe-Wong Effect, see Wan (2004)) and creates jobs for labor and utilizes local land, facilities and utilities.

${ }^{7}$ This institution lowers manufacturing cost, facilitates information acquisition and also subsidizes export-processing by leaving imported inputs free from tariffs which funded the government. Like Xi Zhongxun later, Li received the discretion to relieve the special zone from all laws and regulations which remained administratively or fiscally necessary elsewhere in Taiwan so as to attract Overseas Chinese investors (Li, 1986).

8 Arrow (1962) highlighted the importance of learning-by-doing as a source for growth.

${ }^{9}$ Bhagwati (1999) pointed out that what is truly miraculous in East Asian productivity and growth is that in their capital investment, there is much advantage for learning on the up-to-date equipment; on such equipment, there is a huge gap between the marginal social product and the acquisition price; and this coordination failure calls for appropriate government remedy.

${ }^{10}$ Stiglitz and Greenwald (2014) identified that most of the untapped learning opportunities are in the developing rather than in the developed economies.
} 
learning-by-doing at its micro-foundations. In practice, the definitive feature of SEZ is the tendency for continued skill upgrading, to remedy coordination failures caused by crosssector externalities. There is much dynamic complementarity, along the evolving supply chain.

\subsection{A case of leapfrogging: Taiwan's semiconductor foundries}

While the first two cases exemplify how industrial policy works for catching-up, three intriguing questions come up. First, since government failures lurk on the growth path, as cautioned by Zhang, can they be avoided in policy design? Secondly, since using compass economies risks the disapproval of the template country, as forewarned by Lin, can the technological follower and leader escape Thucydides trap? ${ }^{11}$ Thirdly, since both market-for-technology and learning-from-exporting aim at catching-up, can the technology follower embark on leapfrogging?

A paradigm case is found in Taiwan's semiconductor foundries. This example can serve as an ideal, in answering positively all the three questions above. In particular, it qualifies as leapfrogging by its institutional innovation (or innovation in business methods).

The Taiwan Semiconductor Manufacturing Company (TSMC), started in 1987, is special in its exceptional success, lasting so far over its 31-years history.

Formally, as exceptions prove rules, the most relevant question here is the following: Should any of the challengers of TSMC in this foundry sector - especially the other spin-off firm, UMC - succeeded and TSMC failed, does that affect what the foundry example proves for the study of industrial policy as a triple exception? The answer must be, not at all.

For evidential assessment, we shall trace the details of the case history here, explore the implications in the next sub-section and present a game-theoretic illustration of the foundry problem in Appendix A.

To be brief, TSMC arose in Taiwan in a three-step process in trials and errors:

(1) Technology transfer in 1975. Taiwan's government laboratory, Industrial Technology Research Institute (ITRI), bought from RCA the Complementary Metal Oxide Semiconductor (CMOS) technology for integrated circuits (IC). Although the technology transferred was not state-of-the-art, what were transferred included a complete set of designing, testing, quality control, procurement accounting and data management, in addition to engineering and manufacturing, which were very helpful for later industrial production. ${ }^{12}$ But with limited R\&D resources at ITRI, no technology upgrading was in sight. ${ }^{13}$

(2) Commercialization in 1980. Motivated by the import substitution drive, ITRI span off the CMOS technology to United Microelectronics Corporation (UMC). Its

\footnotetext{
${ }^{11}$ In the case of China's HSR, China has caused complaint, not only from multinational firms dealing with China, but also from foreign governments such as the US under Trump.

${ }^{12}$ This is the view of Dr D. Yang, the then leader of the RCA training project (Lin, 2011a, p. 8).

13 This is the view of Dr Morris Chang, founder of TSMC (Patterson, 2007).
} 
establishment was to set an example for emulation by private firms. ${ }^{14}$ But UMC manufactured for both itself and local chip designers, mainly for domestic market, not exploring worldwide opportunities (Common Wealth Editors, 1999, pp. 131-134). It follows that the technology gap with the frontier was still widening. ${ }^{15}$

(3) Service innovation in 1987. ITRI span off another consortium, TSMC, to implement a customer-oriented innovation: the pure-play foundry model. This was headed by Morris Chang and employing the Very Large Scale Integration (VLSI) technology in cooperation with Philips from the Netherlands. The expectation was to benefit from Chang, then head of ITRI, his decades-long personal experience and prestige in the US, ${ }^{16}$ and from Philips, the only willing significant investor at the onset, not so much for the technology, but its experience and capacity to serve international market. ${ }^{17}$

In a process coincident to what Lin presently advocates, Chang ascertained the worldwide opportunities and Taiwan's relative latent strength. He decided that the only chance was to start with the world's first pure-play foundry, ${ }^{18}$ pledging that "it will not market any product under its own brand." Specifically, once the fab makes the no-compete promise, it cannot derive any benefit by infringing on the intellectual property of the chip designer.

This opened the floodgate for talented fabless chip-designers worldwide, freeing them from being victimized by the foundry service providers in free-riding. ${ }^{19}$ It also changed the structure of the global semiconductor industry, and made TSMC a top chipmaker worldwide, maintaining half of the world market share in contract manufacturing of semiconductors and beating back all challengers. By 2017, TSMC surpassed Intel in market capitalization.

\subsection{The paradigm case: $T S M C$}

Morris Chang's reasoning in founding TSMC deserves elaboration. First, Taiwan's only latent comparative advantage was in manufacturing, not in other areas. In Chang's own words, "Taiwan possessed substantial number of skilled and eager workers and engineers, but had "no clients line up and was still two generations behind California"' (van Agtmael, 2007, pp. 127-128).

Second, the time was right. This results from two empirical regularities: Moore's 1st Law and Moore's 2nd Law. The First Law is the observation that the number of transistors

\footnotetext{
${ }^{14}$ This is the view of Dr D. Hu, the then director of the entire RCA project (Lin, 2011b, p. 21).

15 This is also the view of Morris Chang (Patterson, 2007).

${ }^{16}$ This is the view of Dr C. Shih, the then leader of the VLSI project (Lin, 2011c, p. 18).

${ }^{17}$ Initially $80 \%$ of the technology used by TSMC was within the portfolio available to Philips, by cross-licensing and so on, thus pre-empting any legal complaints by foreign rivals (Matthews and Cho, 2000).

${ }^{18}$ From newly available information (e.g., Lin, 2011b,c,d) inaccessible in earlier researches (e.g., Tung, 2001), Robert Tsao, long-time head of UMC, claimed that UMC had proposed to provide foundry service before TSMC was set up, but the idea was rejected on the advice of Morris Chang. However, while the concept of foundry service was first from Carver Mead around 1980, Tsao's proposal was more of a membership alliance and did not involve any irrevocable no compete promise as in the pure-play model, which is essential to attract foreign chip designers as clients to Taiwan.

${ }^{19}$ Many early clients, such as Broadcom, Marvell, nVidia and Qualcomm, started rather small and grew into global giants (Perry, 2011).
} 


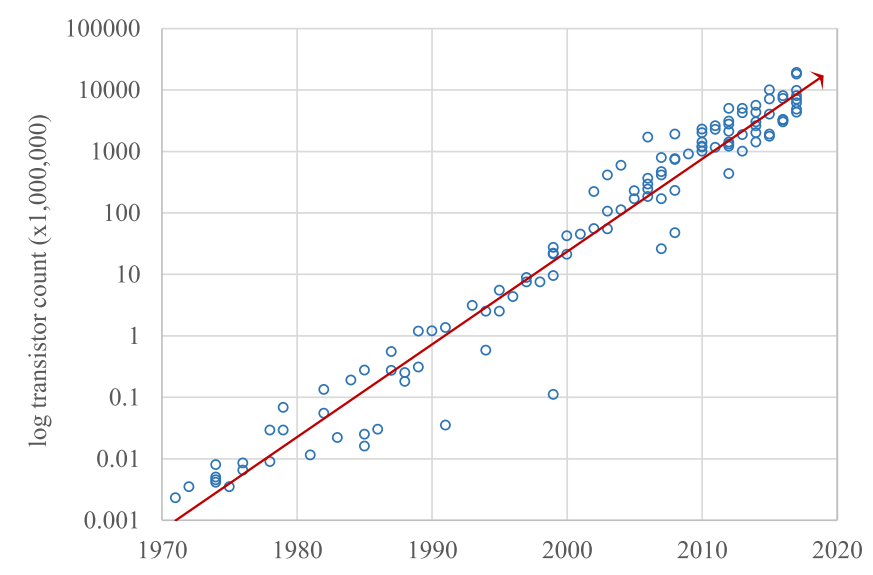

Source: Adapted from https://en.wikipedia.org/wiki/Transistor_count.

Figure 1. Moore's First Law (Transistor Count Per Chip)

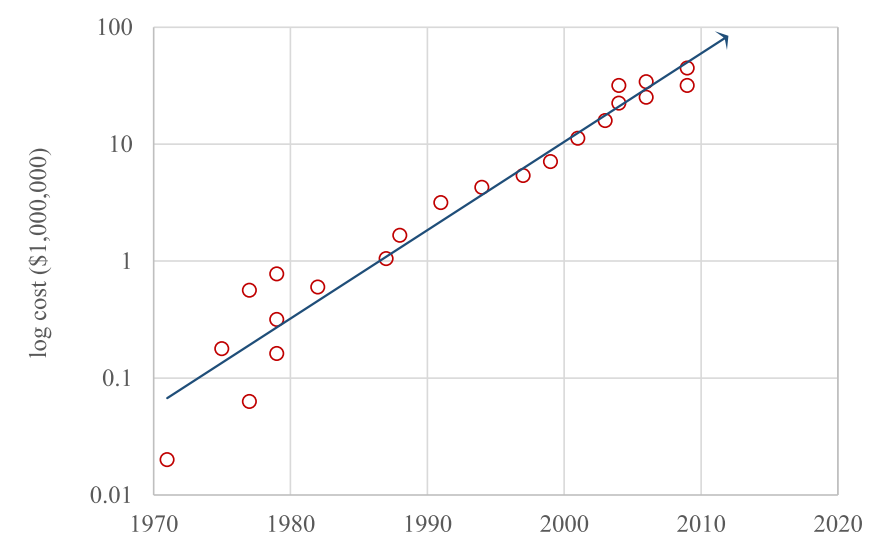

Source: Adapted from http://www.monolithic3d.com/uploads/6/0/5/5/6055488/6542661_orig.jpg.

Figure 2. Moore's Second Law (Cost of Leading-Edge Lithography Tools)

in a dense IC doubles approximately every two years. This is shown with the semi-log plot of Figure 1, in which rival firms use varying IC technologies at various times. This everimproving technology opens doors for both the promise of continued innovation and the constant threat of unpredictable obsolescence.

The Second Law suggests that various capital costs of a semiconductor fab, including lithographic equipment, also increase exponentially over time, which increasingly makes the fabs unaffordable to most firms. This is shown with the semi-log plot of Figure 2, in which rival firms pay costs of varying lithographic equipment at various times. ${ }^{20}$ Thus, would-be IC designers need merchant foundries (such as Fujitsu, IBM, NEC, TI and

\footnotetext{
${ }^{20}$ The long time series for the cost of lithograph equipment signifies that progressively improved tools are deployed to etch ever-finer chip features in miniaturization, which is observed under Moore's 1st Law.
} 
Toshiba) that offer the production service at a fee, hopefully fast enough before the next wave of creative destruction.

The two Moore's laws reflect a common fact: technology gets increasingly complex in production, calling both for close coordination between the designer and the manufacturer $^{21}$ and in resolution of conflicts between the two hopefully in a reasonable time frame, ${ }^{22}$ in case the fab free-rides on the designer's costly effort.

In sum, Taiwan's foundry qualifies as a paradigm case for industrial policy in three ways $^{23}$ :

A. to sink or swim, a spun-off firm is in no way to cause government failure;

B. with substitution of none and as complement to all, there is no Thucydides Trap;

C. to serve as everyone's foundry, the leapfrog idea of a pure-play model is born.

The record of TSMC shows Morris Chang is exceptional both as a policy-maker to assess and exploit Taiwan's comparative advantage and as a foundry manager to deploy the available resources, including his own reputation and insight, to identify and target where it does the most good. The former is relevant for industrial policy, the latter concerns business management. In business, no leader is invincible without sufficient resources: scale economy matters. Working with the market mechanism is not the whole story. Chang as manager, succeeded at TSMC, but not at Vanguard (DRAM), TSMC Solid State Lighting (LED) nor TSMC Solar (solar energy). Each failed project was to spread risk, in case the foundry business cannot be sustained. Some failure may not be inevitable, in what is always a trial-and-error process by nature. Scale economy matters in all such projects and so does the initial resource. Still, at a pinch, one must always be clear it was the foundry business that matters most to Chang. ${ }^{24}$

TSMC itself would not survive, without an active industrial policy at the onset, on two distinct counts: funds and technology. Each shields the project from a specific vulnerability, to produce semiconductors as a pure-play foundry in Taiwan.

First, on funds: The no-compete promise in the company charter is a two-edged sword. The advantage is to win the trust of fabless chip-designers as clients; the threat is to make itself vulnerable when clients fail. It was precarious to survive on orders from either the small local firms to reverse-engineer simple import products, or the unprofitable second sourcing jobs from multinationals for cheap Taiwanese engineers. Pressed by the government to invest, those few private Taiwanese investors who did, complained bitterly and sold stakes at a loss (Tung, 2001); all multinational electronics firms, except Philips, refused to join. It was only the generous initial government funding at the spin-off that

\footnotetext{
${ }^{21}$ Even in earlier times, there is overwhelming complexity in chip fabrication and a strong need for consultation between the fab and the chip designer, from the point of view of both the fab (James, 2001) and the client (Allan, 2002).

22 A striking story is the case, Apple versus Samsung, which dragged into the eighth year in 2018 (Smith, 2017).

23 The reality is slightly more complex: What has been missed by challengers of TSMC appears to be the latter's practice in relationship-specific investment, identifying the most promising customers to work with. The telling example is TSMC's rejection of the offers of Apple and Qualcomm to buy out exclusively its entire facilities (Perry, 2012). This not only reduces risks, but also keeps the flexibility for future small rising stars like nVidia in the past.

${ }^{24}$ This was seen in the case for the rise by GlobalFoundries, backed with the Abu Dhabi public fund ATIC. Chang predicted this challenge as a tough fight and triumphed with total commitment and frugality, as well as confidence (Nystedt, 2009).
} 
enabled TSMC to survive the early lean years, until around 1990-1992, when overseas fabless chip-designers arrived like a tide (Walker, 2000; Patterson, 2007).

Second, on technology: Taiwan was initially weak in both product design and marketing, as well as in its collection of intellectual property rights. ${ }^{25}$ Here Philips helped by cross-licensing intellectual property rights to sustain most of the TSMC operations in its first year (Matthews and Cho, 2000). This provides a safety umbrella for TSMC and a high profit stream for Philips (Manners, 2008). And Philips, the only major multinational that invested in TSMC, became an investor because it already had extensive investment in Taiwan (Lin, 2006), and so chose to stay "on the Taiwanese government's good side" in exchange for better deals (van Agtmael, 2007). There, government's role mattered.

\section{A Broadened Perspective}

There has been much global interest in those Chinese facts underneath the Lin-Zhang debate. An example is Basu (2017), seeking information for Indian reform for growth. He questioned whether Chinese performance resulted from the use of industrial policy, and whether there was industry targeting. Note that China and India together account for 1/3 of the world population, hence the well-being of these two economies is the concern for many economists, and their policies are consequential to global politics.

For Basu's inquiry, the comparative development of these two economies shed further insight, and Table 1 provides a bird's eye view.

Over the period of 1980-2016, China and India have both outperformed the world GDP in percentage of growth. In contrast, America's income share declined slowly. Basu (2017), is interested that how had China started from a similar position with India in 1980, to rise to what it has become - in multi-dimensional strength. ${ }^{26}$

In a globalized world economy, does the rise of China appear to be due to sheer randomness, or by the same market force working on both China and India? The likely

Table 1. GDP of China, India and USA, 1980 and 2016

\begin{tabular}{rrrrrrrrrrr}
\hline & \multicolumn{3}{c}{ Billions of US Dollars } & & \multicolumn{3}{c}{ Percentage of the World Total } \\
\cline { 2 - 4 } Year & World & USA & China & India & & World & USA & China & India \\
\hline 1980 & 11,172 & 2,863 & 191 & 183 & & 100 & 25.6 & 1.7 & 1.6 \\
2016 & 75,872 & 18,624 & 11,199 & 2,264 & & 100 & 24.5 & 14.8 & 3.0 \\
\hline
\end{tabular}

Source: Calculated from World Development Indicators.

\footnotetext{
${ }^{25}$ By Morris Chang's own initial assessment, such weaknesses might easily be exploited in "IP attacks from other companies" that were "fierce" (Patterson, 2007).

${ }^{26}$ As Jong-Hwa Lee (2014), former Chief Economist of Asian Development Bank, wrote at the founding of the Asian Infrastructure Investment Bank, "China — already the world's largest exporter, manufacturer and international-reserve-asset holder - is poised to overtake the United States as the world's largest economy (measured according to purchasing power parity) this year."
} 
answers are negative to both, as the simple cause is industrial policy. This seems as an additional testimony about the relative merit in the Lin-Zhang exchange over industrial policy. It is also a partial answer to the other question of Basu, namely, China benefited not so much in industrial targeting, but by policy measures to become the Workshop of the World, and gained by technology acquisition. ${ }^{27}$

There is no simper way to describe how the system works in the following three subsections, except by evidence from observed cases.

\subsection{The evolving supply chain}

A report of Worstall (2016) on India's prospect of creating a new supply chain of microelectronics is simple and insightful. This report noted that, first, the start of assembling output of foreign design and foreign brand from imported inputs is easy and is helpful to raise local labor productivity, but its margin in value-added is also very thin. Next, the presence of assembly work stimulates not only the quality upgrading of pre-existing local supplied parts, such as wires and solder, but also the introduction of product varieties with higher value-added. Then, the rising local skill and income will prompt local firms to enter markets with their own outputs.

It follows that industrial policy can play a role. The speed of progress may be influenced by government actions with tariffs, quota and/or other incentives, which work on the cost, demand, as well as entrepreneurial expectations. But misused government action can also slow down development.

\subsection{The maturing economy: China}

Over its historic high growth phase that is focussed on in this paper, the Chinese economy matured under globalization and continued reform. In particular, "the future is always envisioned as better than today and incentives (for government officials) are crafted to make that vision a reality." (Yao, 2011)

Yao explained that along the transition trajectory, under the Beijing Consensus, there were government-owned, but private-managed, town-and-village enterprises with unclear ownership that boosted both production and tax revenue. And there was the dual-track price system which protected inefficient public firms and caused corruption, but promoted supply and benefited society. Institutional efficacy was rated more important than institutional purity. Government officials were promoted by merits (measured by growth) rather than accountability. This incentivized the officialdom and benefited both the officials and the citizen at large, even though income was allowed to become unequal. Believing that "the best is the enemy of the good", much of the society was acquiescent to such development.

In the beginning, it was Deng Xiaoping who launched the Chinese industrial policy, under the principle of fording a stream by feeling the rocks. This resembles the adaptive search by Bellman (1961).

\footnotetext{
${ }^{27}$ In a related but separate paper (Wan and Tung, 2018), we explored the attraction of foreign investment in Bhagwati (1999) by externalities, with evidence: the workers of the successful Seagate first worked and got skill at the failed Rollei, which was attracted by the government to Singapore.
} 
In the real world, as the following events indicate, both host governments and multinationals have learned over time how to seek together win-win outcomes. $\mathrm{Gu}$ and $\mathrm{Xu}$ (1989) reported in the late 1980s, managers of foreign firms complained that they were subject to ad hoc assessments by Chinese officers as well as local firms. They felt that they had no reliable control on their own cost, but were like bulls in the ring, bled until death by everyone all around. But a couple of decades later, Rodrik (2006) noted that by various measures, Chinese officials managed to shape an export mix similar in sophistication to other countries with higher income than China. This boosted Chinese growth. More recently, Barboza (2016) mentioned how China first attracted technology transfer with various investment incentives, but then withdrew the inducements once they have achieved their purpose. Foreign firms (such as Apple and Foxconn) were next prompted to shift production inland, to lower-income sites, helping China to reduce inter-regional income inequality, and raising the quality of Chinese growth. ${ }^{28}$

In short, Chinese officials have succeeded to upgrade China's domestic industry structure, by harnessing the foreign firms to achieve their own agenda in technology. ${ }^{29}$

\subsection{The Indian case}

As for India, Foxconn from Taiwan invested in Chennai around 2006 to produce phones for Nokia from Finland, the then market leader in India. But Nokia failed in global competition later on, against rivals such as Apple. When Nokia shut down its Chennai plant after serious tax disputes with the Indian tax authorities in 2014, Foxconn had to close down its facilities for lack of orders from Nokia. This incurred much local suffering and complaints. Yet in 2016, impressed by the future promise of Indian development, Foxconn set up a new manufacturing unit at Sri City SEZ to produce phones for Xiaomi of China, now a strong rival of Samsung from Korea, in the Indian market. Foxconn hired back many of its former workers and those of Nokia at Chennai, both because it was expected to fulfill moral responsibilities and because it regarded those Indian workers as having "received training" (PTI, 2016).

One can surmise that in hosting the production of the premium product of Apple's iPhones for export, China has gained much technology spillover. This enables the rise of Chinese firms like Xiaomi as well as the latter's local rivals, not only in supplying their home market (something Indian firms have achieved as well), but also in exporting successfully abroad to markets like Indonesia, against Samsung of Korea.

Relative to their Chinese counterparts, both the harnessing of foreign firms for one's own agenda and the acquisition of imported technology for exporting to the world market are what have not been doing that much yet, respectively, by Indian government and Indian firms. There are of course historical and institutional reasons that India should achieve similar goals, but by means different from those implemented in China.

\footnotetext{
${ }^{28}$ This policy for industrial upgrading is called vacating the cage to change the bird (in Chinese, 騰籠換鳥), which began under Wang Yang in Guangdong around 2007. President Xi himself had implemented such policy in Zhejiang in a smaller scale in 2006, before he was transferred away in 2007. He emphasized at the time to be considerate with both the new and the old birds (foreign firms): to re-purpose and redeploy them, but not to neglect the interest of the latter (Mingpao, 2017). ${ }^{29}$ Clearly, what China has done is beyond the positive non-interventionism of Hong Kong, as mentioned in footnote 5.
} 
However, a common theme for both India and China is that developing countries with a promising future can motivate successful multinationals working for their own agendas in win-win outcomes. What is more, given China's head start in time, it would be advantageous to scrutinizing China's record, for what was done wrong and right.

\subsection{The Brazilian case}

In sharp contrast to India and China in the Asian Drama, heavy restriction of imported inputs and active unionism, among other factors, have slowed down the growth of the electronics sector in Brazil.

In Brazil, Foxconn started the production of iPhone for Apple, as the only case to produce such premium product outside of China, with ambitious plans for expansion under the market for technology program with high import tariffs (Haynes, 2015). This was supposedly at the cost of revenue loss, causing budgetary deficits, and then inflation. Under inflationary pressure, labor disputes led to strikes (Kahn, 2014). The Brazilian union leaders then regarded this outcome as a success worthy of international emulation, based on progressive legislation and unyielding union activism (Greene, 2012).

The denouement suggests some other lessons as well. Without the scale economy, iPhones produced in Brazil were marketed at the highest unit price in the world and sold only to the few domestic elites, leaving expansion plans unfulfilled (Haynes, 2015). This seems to agree with the prediction of critics that both MNCs are perfidious, and the warning that the industrial policy frequently fails by Zhang, but also the explanation of Lin that over-reaching causes failures, even though success could have been achieved. Here, the failure is seized in the jaws of success.

Brazil can be faulted on two counts: a misidentified comparative advantage and an inappropriate policy priority. For the first point, Brazil insists on assembling premium product at home, like China, behind high tariffs, but it does not have certain advantages that China enjoys: a large domestic market, and a sufficiently productive labor force. Secondly, while union leaders in Brazil have perhaps overly emphasized on worker welfare at the expense of technology upgrading, East Asian economies have avoided disruptive labor strikes $^{30}$ to attract foreign investors to bring in needed technology.

\subsection{Some implication}

There are a couple of caveats to make. First, while industrial policies have brought to China the fruits of economic growth, the country also meets undesirable challenges in environment, internal debts and so on. On institutional or aspirational grounds, India, Brazil, or any other economy seeking to catch up, must decide whether the Chinese or other alternative transitional path is the most suitable.

Second, an important implication here is, conflicts between economies should and can be avoided, or ameliorated, under industrial policy, behind both the prudent statement of

\footnotetext{
${ }^{30}$ For example, in Singapore, compulsory arbitration was used for labor disputes; in Japan, Spring Struggle is limited by convention as a one-day affair.
} 
Lin that the advanced economies may be reluctant to serve as the targeted template economy, and our highlighting of the example of TSMC as a paradigm case of industrial policy for win-win solutions.

Once the conflict of interest sharpens across the borders, outcome in trade and development can no longer be decided by the usual type of unconstrained policy-making of individual national governments. Rather, the intention and capability of the contesting parties matter, though none of which can be measured with any precision in advance. $^{31}$

Furthermore, geo-political factors enter into the policy-making of governments. A classic example is how the rising powers of Imperial Germany and the U.S. interacted differently with the ruling power of Britain around WWI, with German recalcitrance ended less satisfactorily than American accommodation. Sun (2013) used this example to show what he believes China can expect in dealing with the U.S. facing the Thucydides trap.

\section{Conclusion}

This study was motivated by Chinese facts underlying the exchange by Lin and Zhang on industrial policy: Zhang is against industrial policy, due to frequent failures and abuses by rent-seeking policy-makers; Lin is for industrial policy, with close argument, historical sweep and an actionable agenda of informed trial-and-error process.

Their exchange opened the quest to solve a three-fold challenge regarding industrial policy:

A. as an initiative against market failure with little concern on government failure;

B. for growth as a technology follower without antagonizing the advanced economies;

C. leapfrogging by business innovation to activate complementary coevolution.

This involves studying the paradigm case, encouraged by Lin, of Taiwan's TSMC, along with two other important examples from China. The fact-finding into policy-making across the Taiwan Strait has a broader purpose. Interest in East Asia realities is keen abroad to scholars like Basu. Though recent growth of India and China outdistances performance elsewhere in the world, cumulatively China has moved in such a way over the last 40 years relative to India. Therefore, it is worthwhile to seek for replicable experiences.

As obiter dicta, some remarks are left for future inquiry. First, the ongoing US-China trade dispute is most likely the result of China's approaching the technological frontier, like the US-Japan trade-conflict decades ago. It is beyond the scope of this study to discuss in detail about conflict avoidance or resolution, which we shall address the issue elsewhere. But the current situation clearly confirms the necessity to take the three-fold challenge

\footnotetext{
${ }^{31}$ One might compare Ernst (2016) and PCAST (2017) about the Made in China 2025 plan announced in 2015 by the Chinese government. To the former, by its time frame, the Chinese document is indicative planning, not a time-line of implementation, thus win-win coevolution may continue. Yet to the latter, serious friction is imminent.
} 
seriously in advance in the quest of catching-up. And more should be explored in the future.

Secondly, in methodology, the work here suggests the usefulness of both game theory and the case method, which are not always employed. Game theory is advantageous to researches on interactions by forward-looking decision-makers, and case method, which is more heavily used in other disciplines — from medicine to military science — for weighty contexts of life and death, proves invaluable when purely statistical studies are challenging to pursue for availability of sufficient data.

\section{Acknowledgment}

The authors thank Kaushik Basu and Justin Lin for advice on emphasis, and remarks of Larry Blume, Wei-Torng Juang, Erik Thorbecke, Yong Wang, and two anonymous referees. We are also thankful for conference feedbacks, as this paper was given in 2017 in the Growth II Conference, Seattle, The New Structural Economics Conference, Beijing and SERC Conference, Singapore. Finally, the second author appreciates encouragements from Simone Clemhout and the late Tapan Mitra.

\section{Appendix A. A Multi-stage Extensive Game Model for the Pure-Play Foundry}

\section{A.1. Introduction}

This appendix demonstrates how innovations in business methods, more specifically, the design of enforceable commitment devices (in a rule-based world), can play catalytic role with sustained global impact. It shows the rise of an institution (like the pure-play foundry) in an economy that is modest in size and a follower in technology (such as Taiwan) can unleash resource allocation across borders (for instance, the rise of fabless chip designers), and shape international specialization in a rather lasting manner (as an example, TSMC can stand challenges from entrants like GlobalFoundries, backed by sovereign wealth funds among the OPECs).

What makes the difference critically depends upon human behavior with both its foibles and strengths: creative destruction, limitations, moral hazards, hold-ups and free-riding behavior that may defeat innovations in technology. But in turn, innovation in institutions can foster commitment, credibility and confidence to ameliorate sufficiently the situation, modifying supply chains in considerable lasting effect.

Conventional elements in economics, such as scale economy and comparative advantage, all play their integral parts. Yet information, expectations and forethought in human interactions are the essence of our story. Hence, we need analytic tools to augment those conventional building blocks, such as convexity and optimization, that neoclassic economists have shared with physicists and engineers. It is here that multi-stage game theory is indispensable to alleviate the constraints of legal institutions (over intellectual property disputes), unleash the technological promises (due to the two Moore's Laws) and justify 
policy measures themselves through the persistence of the historical process (so the world evolves from more than randomness or serendipity).

Much is known from similar issues like the independent central banker against hyperinflation, but continued study is definitely required to understand what conditions are sufficient to guarantee the central banker remaining independent in various societies around the world.

\section{A.2. The basic model}

Consider a game tree in extensive form with imperfect information, for the two players $\mathbf{F}(\mathrm{ab})$ and $\mathbf{D}$ (esigner), in four stages (with simultaneous moves only in Stage 3):

(1) Dedication by Fab (with pre-commitment of no free-riding; credibility matters)

(2) Investment by Designer (investment in R\&D is necessary but with hold-up issues)

(3) Consultation (co-ordination sub-game: consultation and production; transferring information): Fee from $\mathbf{D}$ to $\mathbf{F}$ changed hands; cost of production is also contracted by D here, but paid at next stage.

(4) Marketing (giving rise to moral hazard of free-riding by Fab): Production made, costs paid and sales revenue received, here. Free-riding by $\mathbf{F}$ means the productions and marketing of additional output under separate brand, to increase revenue of $\mathbf{F}$ and to reduce revenue of $\mathbf{D}$. If free-riding violates any previous commitment to "not marketing any own output," $\mathbf{F}$ agrees to pay to $\mathbf{D}$ any penalty as claimed on demand.

There are 23 nodes: 11 non-terminals, each labeled by an ordered pair, its index in Roman numerical, $k \in\{\mathrm{I}, \ldots, \mathrm{XI}\}$, and the next player making choice, $\mathbf{F}$ or $\mathbf{D} ; 12$ terminals, labeled by an ordered pair, its index in Arabic numerical $j \in\{1, \ldots, 12\}$ and the ordered payoff pair at that node $j, \omega_{j}=\left(\omega_{j}^{F}, \omega_{j}^{D}\right)$, for the players, $\mathbf{F}$ and $\mathbf{D}$. In Stage 3 , the simultaneous moves are at each of the two pairs of nodes: (VI and VII) and (VIII and IX). Each pair is linked by a dotted line, as one information set. Each of the other non-terminal nodes is an information set alone. All nodes in any information set have the same next player, with the same pair of choice.

Each node $j$ in an information set is associated with a rooted sub-game tree, $\Gamma_{j}$ with itself as the root.

Of all the 11 sub-game trees, the essence of this exercise is captured by the collection of four sub-game trees, $\Gamma_{j}, j=\mathrm{I}$, III, IV and V. From the root node of each sub-game tree, at each information set, the preferred choice is identifiable by backward induction for the player and shown as a thick branch. This links the root node, all the way to the terminal node, with its sub-game perfect equilibrium payoff pair. 
In the tree diagram, at each of the 11 nodes in the nine labeled information sets, a player has a binary choice, as tabulated Table A.1.

Table A.1. Players, Stages and Choices

\begin{tabular}{|c|c|c|c|c|c|}
\hline & & & & & \\
\hline Cho & & Dedicate & Invest & Consult & Market \\
\hline & Fab & $\begin{array}{r}d \\
\sim d\end{array}$ & & $\begin{aligned} & c^{\prime} \\
\sim & c^{\prime}\end{aligned}$ & $\begin{array}{r}f \\
\sim f\end{array}$ \\
\hline & Designer & & $\begin{aligned} & i \\
& \sim i\end{aligned}$ & $\begin{aligned} & c^{\prime \prime} \\
\sim & c^{\prime \prime}\end{aligned}$ & \\
\hline
\end{tabular}

One may now display the game tree in Fig. A.1.

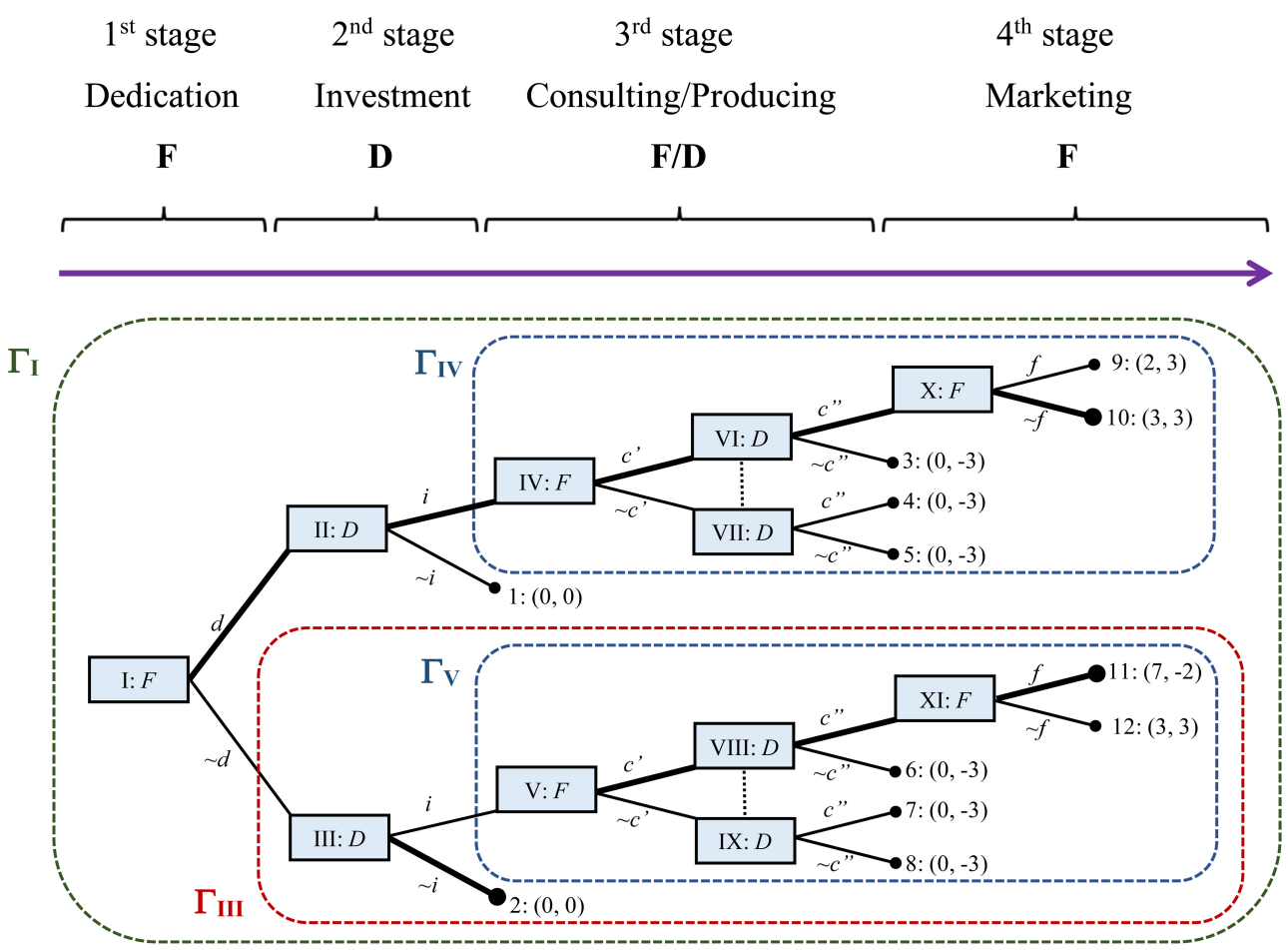

Figure A.1. The Tree Diagram for the Multi-stage Extensive Game 
Payoff pairs at all 12 terminal nodes are summarized in Table A.2. with comments.

Table A.2. Terminal Nodes, Ordered Pay-off Pairs and Remarks

\begin{tabular}{|c|c|c|}
\hline Terminal Nodes & $\omega_{j}$ & Remarks \\
\hline \multirow[t]{6}{*}{ Value of $j$} & $(0,0)$ & Inhibited outcome to $\mathbf{D}$, lost opportunities at node 10 , to $\mathbf{D}$ and $\mathbf{F}$ \\
\hline & $(0,-3)$ & Aborted outcome to $\mathbf{D}$, forfeiting R\&D, worse than nodes 1 and 2 \\
\hline & $(2,3)$ & Penalty outcome pre-committed by $\mathbf{F}$ to $\mathbf{D}$ to avoid nodes 1 to 8 \\
\hline & $(3,3)$ & Desired outcome, supported by pre-commitment of $\mathbf{F}$ \\
\hline & $(7,-2)$ & Free-riding causes $\mathbf{D}$ to go to node 2 \\
\hline & $(3,3)$ & Desired outcome, but thwarted if $\mathbf{F}$ free-rides to node 11 \\
\hline
\end{tabular}

Proposition. The equilibrium ordered payoff pairs for four selected sub-games are tabulated in Table A.3:

Table A.3. Selective Sub-Games, Equilibrium Terminal Nodes

\begin{tabular}{|c|c|c|}
\hline Sub-Games & Sub-Game Terminal Node & Payoff \\
\hline$\Gamma_{\mathrm{I}}$ & 10 & $(3,3)$ \\
\hline$\Gamma_{\mathrm{III}}$ & 2 & $(0,0)$ \\
\hline$\Gamma_{\mathrm{IV}}$ & 10 & $(3,3)$ \\
\hline$\Gamma_{\mathrm{V}}$ & 12 & $(7,-2)$ \\
\hline
\end{tabular}

\section{A.3. Economic interpretation}

Consider the following:

2 products $\{$ Original, Improved $\}$, each defined by an ordered pair of functions \{a parabolic Revenue $R(x)$, an affine Cost $C(x)\}$ in output $\boldsymbol{x}$, with four parameters $\{a, b, F, m\}$.

Information about product $\mathbf{O}$ is tabulated in Table A.4:

Table A.4. Parameters of Good O

\begin{tabular}{lc}
\hline Parameters & Product Original \\
\hline Parabolic revenue: $R=a \cdot x-b \cdot x^{2}$ & $a^{O}=20$ \\
& $b^{O}=9$ \\
Affine cost: $C=F+m \cdot x$ & $F^{O}=6$ \\
$F=F_{1}+F_{2}$ & $m^{O}=2$ \\
$F_{1}:$ fabrication fee & $F_{1}=3$ \\
$F_{2}:$ R\&D investment & $F_{2}=3$ \\
\hline
\end{tabular}


We now introduce five scenarios.

\section{Scenario (1)}

Start now with the initial intent for the original good $\mathbf{O}$, in the ideal case as Scenario (1), at terminal node 12, but thwarted by free-riding (Figure A.2). It is the basis to design the credible commitment device, which is used to support the equilibrium outcome in subgame $\Gamma_{\text {IV }}$, after considering the false starts in sub-games $\Gamma_{\mathrm{V}}$ and $\Gamma_{\mathrm{III}}$, by imbedding $\Gamma_{\mathrm{IV}}$ as part of $\Gamma_{\mathrm{I}}$, which is the main purpose of this entire exercise. At the equilibrium price of 11 , 1 unit is produced, with net profit of 3 , and a substantial consumer surplus (striped area).

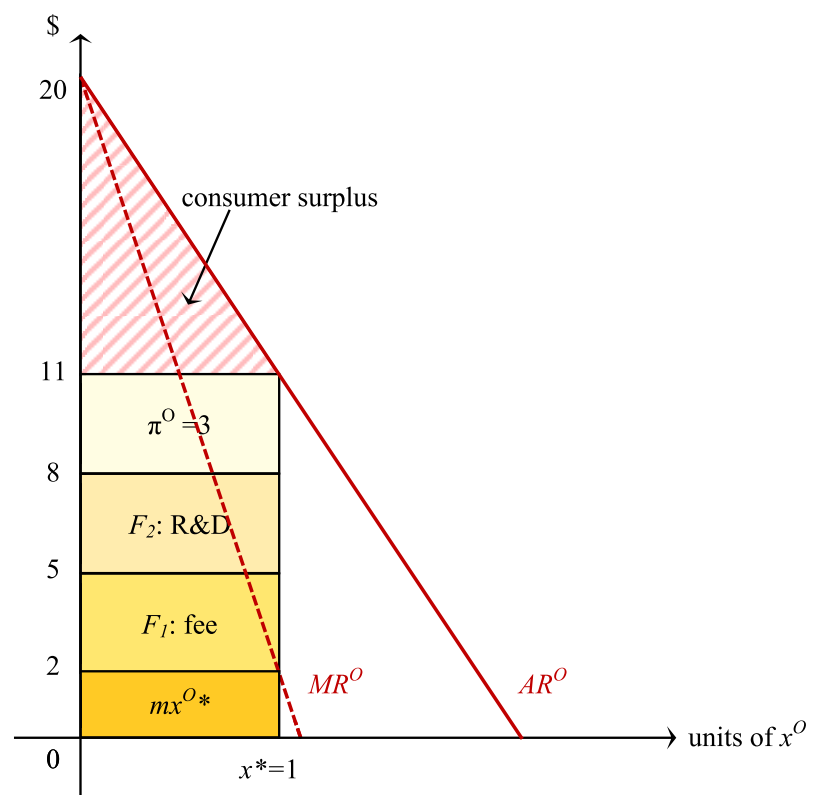

Figure A.2. Ideal Scenario for Original Good O

\section{Scenario (2)}

This is the case of free-riding, at the equilibrium terminal node 11 , under sub-game $\Gamma_{\mathrm{V}}$ that is depicted in the Jevons diagram of Figure A.3. In this case, $\mathbf{F}$ introduces the supposedly "improved good" I for opportunistic purposes in Stage 4, where the planned supply of original good $\mathbf{O}$ is already decided at $x^{O *} \equiv 1$. Information of both good $\mathbf{I}$ and good $\mathbf{O}$ are tabulated in Table A.5. The duopoly prices for goods $\mathbf{I}$ and $\mathbf{O}$ are 10/3 and 6, respectively, with 3 and 1 units produced. The net profit after fee is -3 for $\mathbf{D}$, and 7 for $\mathbf{F}$.

Three points deserve attention. First, the appearance of the so-called improved product took 3 units of market by swinging the average product curve from the vertical line, $x^{I}=0$ (marked under the horizontal axis, from the right) to $A R_{\text {duo }}^{I}$ (line $s t$ ) indicated by the labeled arrow (1). This created for the free-riding $\mathbf{F}$ an increase of payoff of 4 .

Secondly, the shrinkage of the market for the original good $x^{O}$ from $A R^{O}$ to $A R_{\text {duo }}^{O}$ so that the downward-sloping line crosses the broken vertical supply line $M R^{O}$ at price $=6$ on point $q$ rather than price $=11$ at $r$, indicated by the labeled arrow (2). This causes player $\mathbf{D}$ to suffer net loss 2 rather than net profit 3. 


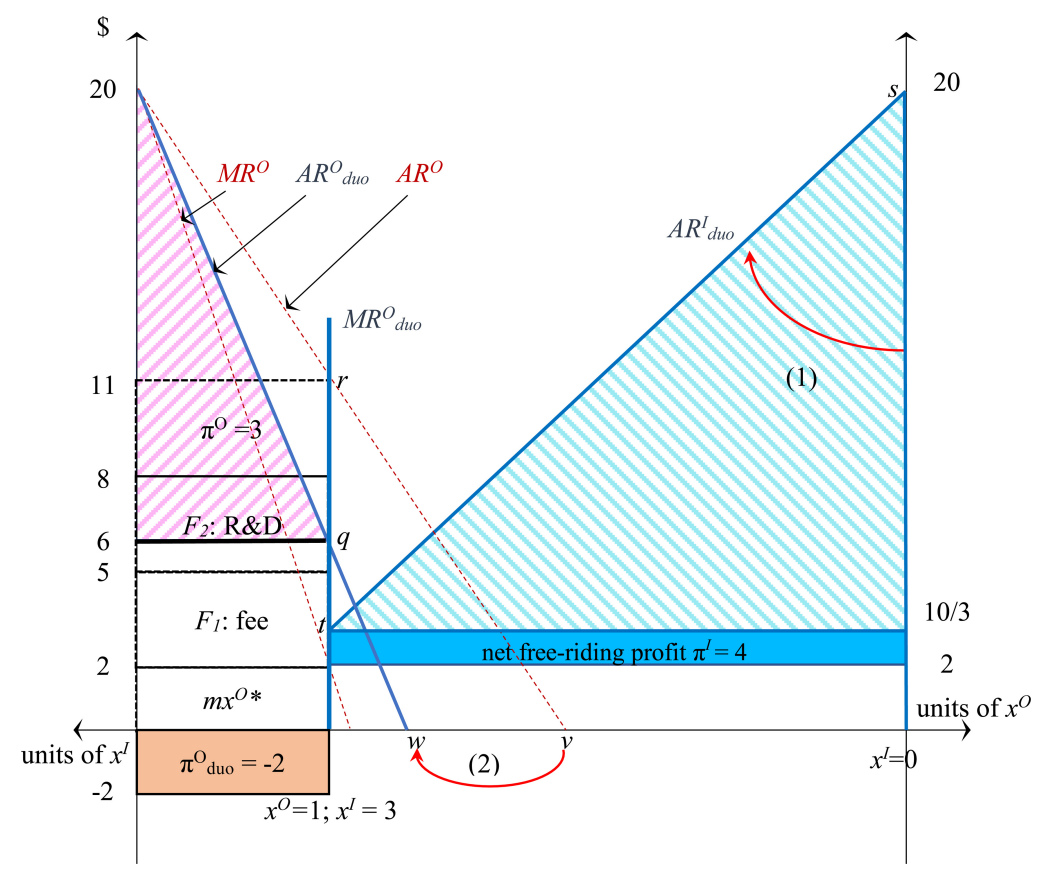

Figure A.3. Duopoly with the Entry of the "Improved Good" by Free-riding

Table A.5. Parameters and Values of Good $\mathbf{O}$ and Good $\mathbf{I}$

\begin{tabular}{lll}
\hline & \multicolumn{2}{c}{ Product } \\
\cline { 2 - 3 } Parameters & Original & Improved \\
\hline Parabolic revenue: $R=a \cdot x-b \cdot x^{2}$ & $a^{O}=20$ & $a^{I}=20$ \\
& $b^{O}=14$ & $b^{I}=50 / 9$ \\
Affine cost: $C=F+m \cdot x$ & $F^{O}=6$ & $F^{I}=0$ \\
$F=F_{1}+F_{2}$ & $m^{O}=2$ & $m^{I}=2$ \\
$F_{1}$ : fabrication fee & $F_{1}=3$ & 0 \\
$F_{2}$ : R\&D investment & $F_{2}=3$ & 0 \\
\hline
\end{tabular}

Thirdly, there is also an expected huge increase of consumers' surpluses (shown by the two striped areas in the diagram) with implications to be discussed later.

\section{Scenario (3)}

However, a negative terminal payoff for designer $\mathbf{D}$ is clearly an unrealistic prospect, should chip designers have realistic forethought and operate by calculated risk. Avoiding legally unpromising prospects, $\mathbf{D}$ would forego investing in $\mathrm{R} \& \mathrm{D}$.

\section{Scenario (4)}

With the above considerations, the fab $\mathbf{F}$ may choose to induce $\mathbf{D}$ to go through the joint venture by offering some credible commitment devices, such as announcing in its corporate 
charter of not engaging in the marketing any product under its own brand, which is a necessary condition for free-riding. Any breach of promise in marketing own products, whatever the intention and whether or not the intellectual property rights of the client $\mathbf{D}$ is violated, $\mathbf{F}$ would promise to compensate any damage as claimed. In such circumstance, $\mathbf{F}$ would transfer to $\mathbf{D}$ the decline of the latter's payoff of $5=[3-(-2)]$, leaving itself a net payoff of $2=7-5$, which is lower than 3 , the promised income from fabrication fee if it has not behaved opportunistically.

Under the credible commitment device described above, a pure-play foundry would be able to induce far-sighted designers globally to enter into the market, under Scenario (5) at terminal node 10. This is the equilibrium sub-game outcome for both $\Gamma_{\mathrm{IV}}$ and $\Gamma_{\mathrm{I}}$ that is equivalent to the ideal but un-reachable node 12 .

The practical value of such a credible commitment device is due to the impractical alternative to appeal to court for any injury suffered under free-riding, since the producer of an improved product is likely to argue that the new output is the fruit of its own effort, innovation by serendipity, or information by open-source channels protected by law, and further argue that consumers as innocent third parties have gained by its action in introducing the new output.

\section{Scenario (5)}

Now in a case when $\mathbf{F}$ is a "lazy" IDM who does no R\&D, but takes order from fabless designers, this $\mathbf{F}$ will not even pretend any improved product, but just pockets the production fee, 3, avoids own R\&D and produces on its own with the information gained during consultation, in a classical equilibrium of Cournot's quantity duopoly (not Bertrand's price duopoly). The price, outputs for $\mathbf{F}$ itself and $\mathbf{D}$ will be $(8,2 / 3,2 / 3)$, with gross profit 4 for both, and the final payoffs for $\mathbf{F}$ and $\mathbf{D}$ will be $(7,2)$ again, at node 11 .

\section{References}

Allan, G (2002). A marriage of unequals. Electronics Design Chain, Summer Vol. 1, pp. 17-20. Retrieved from http://www.designchain.com/featurearticle.asp?id=1\&issue=summer02 (February 1, 2015).

Allison, G (2017). Destined for War: Can America and China Escape Thucydides's Trap? New York: Houghton Mifflin Harcourt.

Arrow, K (1962). The economic implications of learning by doing. The Review of Economic Studies, 29(3), 155-173.

Baraniuk, C (2018). How China's giant solar farms are transforming world energy. Retrieved from http://www.bbc.com/future/story/20180822-why-china-is-transforming-the-worlds-solar-energy (November 16, 2018).

Barboza, D (2016). How China built “iPhone City” with billions in Perks for Apple's partner. The New York Times, December 29, 2016.

Basu, K (2017). Reviving India's Economy. Project Syndicate. Retrieved from https://www.project-syndicate.org/commentary/reversing-india-growth-slowdown-by-kaushik-basu-2017-09? barrier=accessreg (February 1, 2018).

Bellman, RE (1961). Adaptive Control Processes - A Guided Tour. Princeton, NJ: Princeton University Press. 
Bhagwati, J (1958). Immiserizing growth: A geometrical note. Review of Economic Studies, 25, 201-205.

Bhagwati, J (1999). The "Miracle" that did happen: Understanding East Asia in comparative perspective. In Taiwan's Development Experience: Lessons on Roles of Government and Market, E Thorbecke and H Wan (eds.), pp. 21-39. Boston: Kluwer, Academic Press.

Chang, H-J (2002). Kicking Away the Ladder: Development Strategy in Historical Perspective. London: Anthem Press.

Chen, D (2008). Decision formation on setting the special economic zone before and after the $3^{\text {rd }}$ Plenary Session of the $11^{\text {th }}$ Central Committee of the Chinese Communist Party. History of CPC in Beijing, No. 2 (in Chinese).

Chen, X-Y and N Wang (2010). The birth and growth of Chinese-style high-speed railway. Huanqiu (Global), Feb. 25, 2010. Retrieved from http://news.sina.com.cn/c/sd/2010-02-25/ 095119737027_3.shtml (February 1, 2018) (in Chinese).

China Economic Net (2016). Justin Lin vs. Weiying Zhang: An authentic record of the industrial policy debate. China Economic Net. Retrieved from http://www.ce.cn/macro/more/201611/22/ t20161122_18002115.shtml (February 1, 2018) (in Chinese).

Common Wealth Editors (eds.) (1999). The Legend of UMC Hegemony. Taipei: Common Wealth Magazine (in Chinese).

Ernst, D (2016). China's bold strategy for semiconductors - Zero-sum game or catalyst for cooperation. East-West Center Working Paper.

Friedman, M (1998). If only the United States were as free as Hong Kong. Hoover Digest, No. 1 (Reprinted from the Wall Street Journal, July 8, 1997).

Friedman, M (2006). Hong Kong wrong. Wall Street Journal, October 6, 2006.

Gerschenkron, A (1962). Economic Backwardness in Historical Perspective: A Book of Essays. Cambridge, MA: Belknap Press of Harvard University Press.

Greene, J (2012). Could Foxconn's factory in Brazil be a model for Apple production? Retrieved from https://www.cnet.com/news/could-foxconns-factory-in-brazil-be-a-model-forapple-production/ (February 1, 2018).

Gu, G-X and X-M Xu (1989). Survey of foreign-funded enterprises in Shanghai. Fudan Journal (Social Sciences Edition), 4, 14-25 (in Chinese).

Hamada, K (2003). The Heisei recession: An overview. The Social and Economic Research Institute, Cabinet Office of Japan.

Haynes, B (2015). Brazil's iPhone investment falls short on promises of jobs, lower prices. Retrieved from https://www.reuters.com/article/us-foxconn-brazil-apple-insight/brazils-iphoneinvestment-falls-short-on-promises-of-jobs-lower-prices-idUSKBN0N40CP20150413 (February 1, 2018).

Ishihara, S (Frank Baldwin trans.) (1991). The Japan That Can Say No: Why Japan Will Be First Among Equals. New York: Simon \& Schuster.

James, D (2001). Inside TSMC. Upside Magazine. Retrieved from http://www.bsicorp.net/ TaiwanArticle.htm (February 1, 2018).

Kahn, J (2014). IPhone production at Foxconn's Brazil factory halts as workers strike. Retrieved from https://9to5mac.com/2014/09/17/iphone-production-at-foxconns-brazil-factory-halts-asworkers-strike/.

Kornai, J (1979). Economics of Shortage. Amsterdam: North-Holland.

Kynge, J, M Peel and B Bland (2017). China's railway diplomacy hits the buffers. Financial Times, July 17.

Lee, J-H (2014). China's New World Order. Project Syndicate. Retrieved from https://www. project-syndicate.org/commentary/china-global-governance-by-lee-jong-wha-2014-11 (February 1, 2018). 
$\mathrm{Li}$, KT (1986). The formation and implementation of the export processing zone measures. EPZ Newsletters, 21(12), 4-7 (in Chinese).

Lin, C-W (2006). The model of Taiwan's high-tech industry: TSMC. In The Silicon Dragon: HighTech Industry in Taiwan, T Terence and B-S Cheng (eds.), pp. 78-94. Cheltenham, UK: Edward Elgar Publishing Limited.

Lin, L-F (2011a). Taiwanese IT Pioneers: D.Y. (Ding-Yuan) Yang. CHM Reference number: X6290.2012, Computer History Museum.

Lin, L-F (2011b). Taiwanese IT Pioneers: Robert H. C. Tsao. CHM Reference number: X6291.2012, Computer History Museum.

Lin, L-F (2011c). Taiwanese IT Pioneers: Chingtay Shih. CHM Reference number: X6259.2012, Computer History Museum.

Lin, L-F (2011d). Taiwanese IT Pioneers: Ding Hua Hu. CHM Reference number: X6289.2012, Computer History Museum.

Manners, D (2008). The best semiconductor investment ever made. Retrieved from http://www. electronicsweekly.com/blogs/mannerisms/manufacturing-mannerisms/the-best-semiconductorinvestm-2008-08/ (November 16, 2018).

Matthews, J and D-S Cho (2000). Tiger Technology: The Creation of a Semiconductor Industry in East Asia. Cambridge: Cambridge University Press.

McKinsey \& Company (2011). McKinsey on Semiconductors. McKinsey \& Company.

Mingpao (2017). Canton implemented "Vacating the cage to change the bird," in Preparation for "Supply-Side Reform." Mingpao, October 2, 2017 (in Chinese).

Myrdal, G (1968). Asian Drama: An Inquiry into the Poverty of Nations (Vols. I, II and III). New York: Pantheon.

Nystedt, D (2009). TSMC Chairman predicts tough victory over Global Foundries Retrieved from https://www.pcworld.com/article/169317/article.html (November 16, 2018).

Patterson, A (2007). Oral History of Morris Chang. Computer History Museum. Retrieved from http://www.semi.org/en/oral-history-interview-morris-chang (February 1, 2018).

PCAST (President's Council of Advisors on Science and Technology) (2017). Ensuring Long-Term U.S. Leadership in Semiconductors - 2017 Report, Influencing China, Improving U.S. Business Climate, Moonshots for Computing, Bioelectronics, Electric Grid, Weather Forecasting. Retrieved from: https://obamawhitehouse.archives.gov/sites/default/files/microsites/ostp/PCAST/pcast_ensuring_long-term_us_leadership_in_semiconductors.pdf (November 16, 2018).

Perry, ST (2011). Morris Chang: Foundry father. Retrieved from https://spectrum.ieee.org/at-work/ tech-careers/morris-chang-foundry-father (February 1, 2018).

Perry, ST (2012). TSMC's Morris Chang says no to Apple, Qualcomm. Retrieved from https:// spectrum.ieee.org/tech-talk/semiconductors/devices/tsmcs-morris-chang-says-no-to-applequalcomm (February 1, 2018).

PTI (2016). Foxconn hires ex-staff of Nokia Chennai plant for AP unit. The Economic Times, July 12.

Rodrik, D (2006). What's so special about China's exports? China and World Economy, 14(5), $1-19$.

Romer, P (2015). Interview on urbanization, charter cities and growth theory. Retrieved from https://paulromer.net/tag/charter-cities/ (February 1, 2018).

Smith, C (2017). The judge in Apple vs. Samsung case is really tired of doing this. Retrieved from http://bgr.com/2017/10/26/apple-vs-samsung-iphone-lawsuit-2018/ (February 1, 2018).

Stiglitz, JE and BC Greenwald (2014). Creating a Learning Society: A New Approach to Growth, Development, and Social Progress. New York: Columbia University Press.

Sun, Xue Feng (2013). Dilemma of China's Rise: Theoretical Reflections and Strategic Choices, Social Science Academic Press. (In Chinese), 352 pages. 
Tung, A-C (2001). Taiwan's semiconductor industry: What the state did and did not. Review of Development Economics, 5(2), 266-288.

Uchida, H (1991). The transfer of electrical technology from the U.S. and Europe to Japan, 18691914. In International Technology Transfer: Europe, Japan and USA, 1700-1914, D Jeremy. Aldershot, UK: Edward Elgar.

van Agtmael, A (2007). The Emerging Markets Century. New York: Free Press.

Walker, RA (2000). Interview with Don Brooks. Retrieved from http://silicongenesis.stanford.edu/ transcripts/brooks.htm (November 16, 2018).

Wan, HY Jr (2004). Economic Development in a Globalized Environment: East Asian Evidences. Berlin, Germany: Springer.

Wan, HY and A-C Tung (2018). Remarks on co-evolutionary growth. Paper presented in the Conference Honoring Professor Mitra, Cornell University, August 18, Ithaca, NY.

World Bank (1993). The East Asian Miracle. New York: Oxford University Press.

Worstall, T (2016). Apple could start manufacturing in India - Reports of plant in Bengaluru. Forbes, December 30, 2016.

Yao, Y (2011). Beijing consensus or Washington consensus: What explains China's economic success. Development Outreach, 1, 26-31. 